L'affinement conduit à la valeur $\left|f_{1}-f_{2}\right|=8$ électrons d'où l'on déduit les deux solutions

$$
\left.\begin{array}{l}
f_{1}=29 \text { électrons } \\
f_{2}=21 \text { électrons }
\end{array}\right\} \text { ou }\left\{\begin{array}{l}
f_{1}=17 \text { électrons } \\
f_{2}=25 \text { électrons }
\end{array}\right.
$$

situées de part et d'autre de la valeur moyenne $1,27 f(\mathrm{U}, \mathrm{Na}) / 2$ $=23$ électrons [densité électronique sur les sites $16(d)$ ].

\section{Extension des domaines par recuit}

Un recuit à $600^{\circ} \mathrm{C}$ à l'air pendant une semaine a été effectué sur quelques cristaux partiellement ordonnés.

Des clichés de rayons $\mathrm{X}$ montrent alors que les noeuds de parité mixte sont devenus ponctuels, ce qui prouve l'ex- tension des domaines. Cet agrandissement des domaines s'est accompagné d'une modification de la densité électronique des sites $4(b)$ et $12(d)$ car l'intensité des noeuds du réseau $P$ s'est considérablement accrue par rapport à celle des noeuds du réseau $F$.

Les mesures d'intensité permettent de déterminer pour $\left|f_{1}-f_{2}\right|$ la nouvelle valeur de 21 électrons.

Un troisième chauffage de 15 jours à $600^{\circ} \mathrm{C}$ sur ces mêmes cristaux poursuit la mise en ordre: la différence de charge sur les deux sites devient égale à 39 électrons.

Enfin, un chauffage plus énergique à $1000^{\circ} \mathrm{C}$ les désordonne complètement et, de plus, modifie leur couleur qui passe de jaune clair à rouge foncé. Cette transformation s'est avérée irréversible et nous nous employons actuellement à en expliquer le mécanisme.

\title{
Notes and News
}

Announcements and other items of crystallographic interest will be published under this heading at the discretion of the Editorial Board. The notes (in duplicate) should be sent to the Executive Secretary of the International Union of Crystallography (J. N. King, International Union of Crystallography, 13 White Friars, Chester CH1 1NZ, England).

\section{Molecular Structure and Dimensions}

Volume 3 of the new reference series published by the International Union of Crystallography and the Crystallographic Data Centre was published in February 1972. The new volume contains classified bibliographic information on organic and organometallic structures published during 1969-71. The arrangement is identical with the first two volumes in the series with entries arranged in chemical classes and extensive cross-references. There are three indexes: author, formula and transition metal. All are cumulative for the years 1935-1971 and give references to entries in Volumes 1, 2 and 3.

Molecular Structures and Dimensions is obtainable directly from the publishers, A. Oosthoek's Uitgevers Mij. N.V., Domstraat 5-13, Utrecht, The Netherlands, from Polycrystal Book Service, P. O. Box 11567, Pittsburgh, Pa. 15238 , U.S.A. or from any bookseller, at a price of Netherlands Guilders 55.00 (U.S. $\$ 17.00$ or $£ 6.50$ at present rates of exchange). Personal subscribers may purchase a copy exclusively for their own use at the special reduced price of Netherlands Guilders 39.00 (U.S. $\$ 12.50$ or $£ 4 \cdot 70$ ).

\section{Crystal Structure Communications}

Crystal Structure Communications is an international quarterly report for rapid communications concerning results of crystal structure analyses and is published by the X-Ray Crystallography Group of the University of Parma, Italy. The Editors are Professor L. Cavalca and Professor M. Nardelli. Contributions must concern structures solved and completely refined, not yet published or in the press and not yet printed. All the papers must be written in English and the authors are free to publish elsewhere the complete reports of these researches. They must, however, be prepared to supply further data and information (e.g. structure factors tables, thermal parameters, etc.) on direct request from readers. Papers are classified in three sections: (1) minerals and inorganic, (2) coordination and metal organic, (3) organic and polymers. Publication commences early in 1972 .

\section{Journal of Crystal and Molecular Structure}

This new journal was first published in 1971 by Plenum Press (London) under the editorship of Dr M. F. C. Ladd, Department of Chemical Physics, University of Surrey, Guildford, Surrey, England. It states that it is concerned with the publication of crystallographic and spectroscopic studies of the structures of crystals, molecules and other atomic assemblies, publishing, in English only, reports of original research as full-length articles or as short communications. It does not publish letters or book reviews.

\section{Crystallographic programs for the IBM 1130 and ICL 1901 A computers}

In addition to the programs mentioned in an earlier note [Acta Cryst. (1969) B25, 1674] we now have available some new programs, suitable for use on the above machines, with $16 \mathrm{~K}$ core, disc storage and no tape drives:

1. Block-diagonal least-squares refinement (isotropic and anisotropic).

2. Centrosymmetric and non-centrosymmetric structurefactor calculation and Fourier summation (two- and threedimensional).

3. Thermal ellipsoid calculation, and rigid-body analysis.

4. Section in an arbitrary plane through a three-dimensional Fourier map.

5. Calculated and difference Patterson map calculation.

The programs are not original; they are merely modifications for these particular computers. On request, a FORTRAN listing and operating instructions will be supplied.

Department of Chemistry

Michael Laing

University of Natal

Durban

South Africa 